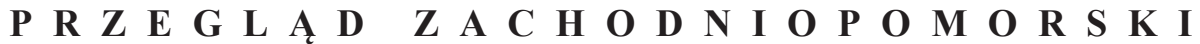 ROCZNIK XXX (LIX) ROK 2015 ZESZYT 2
}

\author{
R E C E N Z J E
}

DOI: 10.18276/pz.2015.2-09

\section{Eckhard Jäger, Die Insel Rügen auf alten Karten. Vier Jahrhunderte Kartografiegeschichte 1532-1885, Husum Druck- und Verlagsgesellschaft 2014, ss. 256}

Eckhard Jäger, niemiecki historyk kartografii, polskiemu czytelnikowi był znany przede wszystkim jako autor rzetelnie opracowanego i starannie wydanego w 1982 r. katalogu Prussia-Karten: 1542-1810². W 1997 r. w tomie IX serii „Z Dziejów Kartografii”, w Materiałach XVII Ogólnopolskiej Konferencji Historyków Kartografii, które stanowiły pokłosie szczecińskiej konferencji, ukazała się jego kolejna - tym razem przeznaczona na polski rynek - publikacja pt. Gedruckte Landkarten der Insel Rügen. Versuch einer Typologie von 1584 bis 1885. W świetle recenzowanej książki ów piętnastostronicowy artykuł był zapowiedzią rozpoczęcia wieloletnich prac badawczych. Zapewne od tamtej pory autor studiował dawne materiały kartograficzne Pomorza, poszukując ich na globalnym rynku antyk-

1 E. Jäger, Prussia-Karten: 1542-1810, Geschichte d. kartographischen Darstellung Ostpreussens vom 16. bis zum 19. Jahrhundert. Entstehung d. Karten, Kosten, Vertrieb, bibliographischer Katalog (Schriften des Nordostdeutschen Kulturwerks Lüneburg), Weissenhorn: Anton H. Konrad Verlag, 1982, ISBN 978-3874371972. warycznym ${ }^{2}$. Konsultował także wyniki swoich badań z właścicielami prywatnych kolekcji, z pracownikami co najmniej 36 europejskich bibliotek, muzeów, archiwów - w tej liczbie m.in. ze śp. Władysławem Filipowiakiem z Muzeum Narodowego w Szczecinie, Krystyną Szykułą z Biblioteki Uniwersyteckiej we Wrocławiu oraz śp. Tomaszem Niewodniczańskim (s. 6). Dopełnieniem wstępnych informacji Jägera o dawnych mapach Rugii był artykuł - zamieszczony w ubiegłorocznej szczecińskiej publikacji Eilharda Lubinusa podróż przez Pomorze - Eilharda Lubinusa mapa Rugii (1609)², w którym autor, omawiając działalność naukową Lubinusa, przedstawił jego ,wielką" mapę Rugii Nova famigerabilis insulae ac ducatus Rugiae descriptio, opublikowaną w Amsterdamie przez Jodocusa Hondiusa w 1609 r. $^{4}$, oraz jej filiacje ${ }^{5}$.

\footnotetext{
2 Jäger jest antykwariuszem w Lüneburgu.

${ }^{3}$ Eilharda Lubinusa podróż przez Pomorze, Szczecin 2013, s. 81-115.

${ }^{4}$ Ibidem, ryc. 6.

${ }^{5}$ Zob. także recenzja L. Szaniawskiej, „Polski Przegląd Kartograficzny" 2014, t. 46, nr 1,
} s. $83-85$. 
Recenzowana publikacja o Rugii różni się od katalogu map Prus warsztatem badawczym oraz sposobem narracji. We wcześniejszym katalogu objętość treści historycznej zawartej w następujących po sobie esejach wraz ze wzbogacającymi go rycinami map lub ich fragmentów, ma się do objętości samego katalogu jak $6: 1$. Trzysta piętnaście opisów katalogowych zamieszczono na 48 stronach. I są to opisy krótkie, ściśle bibliograficzne, z krótkimi uwagami dotyczącymi jedynie filiacji map. W esejach znalazło się wiele informacji o rozwoju na terenie Prus miernictwa, opracowywania map, szkół kartograficznych, produkcji wydawniczej map, a także dane o twórcach map. W katalogu Rugii prawie wszystkie wiadomości związane $\mathrm{z}$ danym egzemplarzem mapy zawarte zostały w jego opisach bibliograficznych, każdorazowo wzbogaconych obrazem całej mapy lub jej fragmentu. Stąd 125 map oraz 47 ich kolejnych wariantów i stanów zajęło ponad 220 stron w drukowanym w tym samym formacie, co wcześniejszy, katalogu.

Poprzedzony kilkustronicowym zarysem historii politycznej Rugii katalog, pomieszczony w publikacji Die Insel Rügen auf alten Karten..., składa się z dwóch części. W pierwszej z nich, obszerniejszej, znalazły się opisy map lądowych, a w drugiej - map morskich. Opisy zostały ułożone chronologicznie, w każdej części niezależnie, ale nadano im wspólną numerację. Układ ten łamany jest jedynie w przypadku kolejnych stanów, które następują bezpośrednio po oryginale, a dopiero za nim idą kolejne edycje. Na przykład opis pierwszego - z 1585 r. - wydania mapy fragmentu Meklemburgii z Rugią Lucasa Janszoona Waghenaera (s. 222) poprzedza opisy dwóch stanów: drugiego datowanego po 1585 r. oraz trzeciego, z 1590 r.; po nim znalazł się opis wydania mapy w 1588 r., anglojęzycznej kopii odbitej $\mathrm{z}$ ponownie wykonanej płyty miedziorytniczej (s. 224).

Przed kartą tytułową katalogu Katalog der Rügen-Karten zamieszczono, jak w każdym profesjonalnie opracowanym katalogu, wyjaśnienie ${ }^{6}$ budowy opisów, tym razem zapisane w trzynastu punktach. Ponieważ opisy w wydawanych w Europie katalogach mają różną budowę (także zawartość oraz kolejność zapisu danych), przytoczę tę podaną przez Jägera, by pokazać warsztat autora, tym bardziej że jest klarowna i można się na niej wzorować. Pierwszą informację o każdej mapie stanowi sformułowane hasło wyszukiwawcze zapisane pogrubionym drukiem. Składa się ono z trzech elementów, oddzielonych od siebie ukośnikiem: numeru pozycji w katalogu, hasła osobowego tożsamego najczęściej z nazwiskiem autora mapy, po którym zapisano datę jej opublikowania. W dalszej kolejności opisu podawane są: pełna forma nazwiska i imienia autora mapy, w przypadku jego braku - wydawcy, pełny tytuł mapy, miejsce zapisu tytułu na mapie oraz paginacja związana z dziełem, w którym mapa była wydana. W następnych trzech punktach umieszczane są dedykacje, mapy poboczne oraz zapisy nadanych drukarzo-

6 Wersja oryginalna tytułu Erläuterungen zur Reihenfolge der Titelei im Kartenkatalog. 
wi lub wydawcy przywilejów. Po nich zapisywane są: zastosowana technika druku, wymiary mapy oraz skala - zawsze podana w postaci ułamka dziesiętnego. Jeżeli na mapie nie ma daty jej druku, to Jäger podaje wyjaśnienie, skąd pochodzi cytowane przez niego datowanie, czyli - dane dotyczące druku dzieła, w którym mapa została wydana, a następnie bibliografię lub katalog, gdzie można znaleźć dalsze wyjaśnienia jej pochodzenia i datowania. Dość obszerne komentarze/uwagi dotyczą współtwórców oraz samych map, ich wykonania, filiacji itp. Każdy opis kończy cytata z literatury, jeśli zaś opisywana mapa jest rękopisem lub znane jest tylko jedno miejsce jej przechowywania, dane te również są uwzględniane w opisie. Stany niektórych map nie zostały przedstawione na ilustracjach i w ich opisie znajduje się stosowna uwaga: „nicht abgebildet”, np. w opisach stanów mapy 94A, 94B i 94C.

Wśród opisów w katalogu map lądowych dominują mapy drukowane. Jednak najstarszą znaną mapą Rugii jest rękopiśmienna, anonimowa mapa bez tytułu z 1532 r., o wymiarach $415 \times 28 \mathrm{~cm}$, w skali około 1 : 250 000. Kolejne dwie, omówione w opisach 2 i 3, także są rękopiśmienne i wyglądają na późniejsze jej kopie. Pierwsza drukowana mapa to $R u$ giae, Vsedomiae et Ivlinae, Wandalicarum insula rum Vera descriptio opracowana i wydana przez Abrahama Orteliusa po raz pierwszy w Theatrum orbis terrarum z 1584 r. Te najwcześniejsze mapy, mało dokładne, poprzedzają mapy narysowane na podstawie pomiarów terenowych. Jako pierwszą autor omawia mapę E. Lubinusa, wydaną przez J. Hondiusa w 1607 r. Jak wynika z katalogu, była ona bardzo długo podstawą rysowania i wydawania map tego obszaru. Dopiero w 1763 r. zastąpiona została nowocześniejszym obrazem na mapie Pomeraniae Citerioris Svedicae ac Principatus Rugiae Tabula... autorstwa profesora matematyki z Greifswaldu, Andreasa Mayera. Pod koniec XVIII w. w tej części państwa pruskiego ponownie wykonano pomiary terenowe $\mathrm{z}$ zastosowaniem pierwszych pomiarów triangulacyjnych i mapa narysowana na ich podstawie przez Friedricha Wilhelma Carla Grafa v. Schmettau była prawdziwie nowoczesnym dokumentem kartograficznym. Katalog map lądowych zamyka mapa wydana w 1885 r. w skali 1 : 100 000, będąca zredukowaną i poprawioną wersją arkusza mapy opracowanej na podstawie zdjęć stolikowych Marchii Brandenburskiej wykonanych w latach 1816-1843, w ramach prac triangulacyjnych kierowanych przez Carla Wilhelma v. Oesfelda, i wydana w 1836 r. w skali $1: 25000$.

Druga część katalogu (zawierająca mapy morskie) Katalog der Rügen-Karten. Teil II: Seekarten składa się z szesnastu opisów. Najdawniejsza z map, Caerte van de zee Custe va[n] Mekelenborch..., opracowana była przez Lucasa Janszoona Waghenaera w skali około 1 : $850000 \mathrm{i}$ wydana w Lejdzie przez Christophera Plantijna w 1585 r. Natomiast dwie najnowsze mapy to: Baltic. Coast of Prussia, sheet I, from the Royal Prussian Survey... wydana przez brytyjską admiralicję w $1855 \mathrm{r}$. 
w skali około 1 : 150000 oraz mapa litografowana przez J. Geisendorfera $\mathrm{Mer} \mathrm{Bal-}$ tique (Rostock-Arkona) w Paryżu w 1867 r. w skali $1: 100000$.

Jako merytoryczne podsumowanie wynikającej z katalogu wiedzy o opisanych lądowych mapach ${ }^{7}$ Rugii Jäger dodał podział na grupy, wyodrębnione według kryterium cech mapy wynikających z filiacji. Pierwszą grupę stanowią mapa Eilharda Lubinusa Nova famiderabilis insulae ac ducatus Rugiae descriptio... wydana przez Jodocusa Hondiusa w 1607 r. w skali około 1 : 200000 oraz wszystkie bezpośrednie kopie i mapy sprawiające wrażenie ich pochodnych. Drugą grupę rozpoczyna mapa Andreasa Mayera wydana w oficynie Tobiasa Conrada Lottera w 1763 r. w skali około 1 : 210 000. Trzecią grupę tworzą arkusze mapy Rugii Friedricha Wilhelma Carla Grafa v. Schmettau z 1794 r. w skali 1 : 220 000, znanej jedynie $\mathrm{z}$ jednego egzemplarza przechowywanego w antykwariacie w Lüneburgu oraz jej późniejsze drukowane kopie, m.in. wydawane przez Daniela Gottliba Reymanna od 1806 r., początkowo jako mapa samodzielna Karte von Schwedisch Pommern und der Insel Rügen..., a później włączone w wieloarkuszową mapę topograficzną w skali 1 : 200 000. Czwartą grupę tworzą warianty mapy Friedricha von Hagenowa Special Charte der Insel Rügen... w skali około 1 : 50 000, wydanej po raz pierwszy w 1829 r. Do piątej grupy Jäger zaliczył, jako oryginał, arkusz Bergen rękopiśmien-

${ }^{7}$ Mapy morskie, opisane w drugiej części katalogu, nie zostały sklasyfikowane. nej mapy topograficznej w skali $1: 25000$ Preussische Urmesstischblatter $\mathrm{z}$ datą narysowania 1836 r. oraz jej warianty wydawane w różnych skalach aż do roku 1885.

Publikacje dopełniają: krótki chronologiczny zestaw (21 pozycji) przewodników po Rugii wydanych w latach 1797-1888, rozwinięcie skrótów funkcji zastosowanych na skatalogowanych mapach, wykaz miar i wag używanych w tym regionie Pomorza, starannie zebrana literatura, indeks osobowy rysowników, rytowników, drukarzy i wydawców. W tej części publikacji (s. 249) zamieszczono zestaw formatów papieru oraz książek w zapisie używanym przez „starodruczników”. Zestaw rozpoczyna format „folio” $\left(2^{\circ}\right)$, a powinien ,plano”. Mapy w atlasach w formacie „folio" takich autorów jak Abraham Ortelius (TOT), Gerard Mercator (Atlas) i wielu innych były drukowane na papierze formatu ,plano”. Także obecnie w antykwariatach szczególnie te mapy po konserwacji są w formacie ,plano”. Świetnym przykładem map ,in plano” są mapy Rugii opisane w katalogu, np. E. Lubinusa wydana przez J. Hondiusa w 1607 r. (s. 33), Lubinusa/Blaeua z 1631 r., Lubinusa/ de Wita... z 1705 r.

Porównując katalog Die Insel Rügen auf alten Karten... z innymi wydanymi w XXI w., można powiedzieć, że jest on bez wątpienia jednym $\mathrm{z}$ lepszych pod względem usystematyzowania treści, a zamieszczony tam logiczny i czytelny układ map pozwala na łatwe wyszukiwanie konkretnego wydania lub stanu. Jest to publikacja z najwyższej półki i stawiam ją 
na tym samym poziomie merytorycznym i technicznym co katalogi: Els mapes del territori de Catalunya durant doscents anys, 1600-1800 wydany przez Institut Cartografic de Catalunya w Barcelonie w 2001 r., trzytomowy katalog dawnych map Ukrainy - tych drukowanych w tomie Ukraina na starodavnih kartah... z 2004 r. - i w kolejnym z 2009 r. oraz map rękopiśmiennych $\mathrm{w}$ tomie Rukopisni karti... z 2011 r. (całość wydana w Kijowie przez wydawnictwo DNVP „Kartografija”), polskie katalogi publikowane przez Towarzystwo Przyjaciół Ossolineum - Romana Wytyczaka Śląsk w dawnej kartografii... (Wrocław 1998) i Mariusza Dworsatschka Imago Silesiae... (Wrocław 2002), a także - chociaż zawierający opisy przeznaczone nie tylko dla fachowców, ale także dla szeroko pomyślanego odbiorcy - katalog The Map Book opracowany przez Petera Barbera, wydany w Londynie 2005 r.
Co więcej, ponieważ omawiana publikacja obejmuje wszystkie odnalezione do tej pory mapy prezentujące Rugię, jest czymś więcej niż tylko katalogiem. Jest ona bibliografią i z tego względu postawiłabym ją na najwyższym podium, wraz z powszechnie docenianym dziełem Rodneya W. Shirleya The Mapping of the World. Early Printed World Maps 14721700 wydanym po raz pierwszy w 1987 r. Obie bibliografie dokumentów kartograficznych, acz znacznie się różniące, charakteryzuje bardzo dobry warsztat badawczy. Bibliografia map Rugii, ze względu na stosunkowo mało znany i mniej fascynujący obiekt geograficzny - w porównaniu z całym światem z dzieła Shirley'a, nie zdobędzie zapewne rozgłosu na światową skalę, ale $\mathrm{z}$ pewnością będzie miała wśród europejskich profesjonalistów i kolekcjonerów dawnych kartografików stosowne grono czytelników. 